
A
$\mathbf{R}$
$\mathbf{T}$
$\mathbf{Y}$
$\mathbf{K}$
$\mathbf{U}$
$\mathbf{L}$

KAROL JASIŃSKI

\title{
RELIGIOUS FAITH AND THE TYPES OF RATIONALITY
}

\section{INTRODUCTION}

In the Fides et ratio encyclical, John Paul II made an important observation that faith and reason were like two wings on which the human spirit rose to the contemplation of truth. In the pope's mind, the desire to know the truth was placed in the human heart by God and finds fulfilment in God, who is the personal Truth.

Reason and religious faith are not two autonomous realities; they can come together and interpenetrate. Contrary to the beliefs of Christian mystics like Bernard de Clairvaux, faith is not only a matter of intuition and contemplation but also a type of knowledge which expands the limits of rational cognition. On the other hand, reason may purify the knowledge acquired through faith and, in accordance with the fides quaerens intellectum method promoted by Anselm of Canterbury, may allow man to better comprehend and explain the truths of the faith.

However, are all types of reason capable of tackling such a challenge? The existence of many types of reason and, consequently, many types of rationality must be taken into account. It seems that faith demands chiefly substantial reason and intellectual cognition, as other types of rationality prove insufficient. 
These deliberations aim to determine the nature of religious faith and various types of rationality, with special emphasis on instrumental rationality. Furthermore, they seek to characterise the link between faith and reason, as well as the insufficiency of instrumental reason in the sphere of faith. Instrumental reason is limited to the practical pursuits, which forces man to rely on a different type of mental activity in other spheres of life, such as religiousness.

\section{THE NATURE OF RELIGIOUS FAITH}

All attempts at defining the notion of religious faith must be preceded by a consideration of its colloquial meaning. The words "faith" and "believe" are used in a variety of senses to describe the following situations and states: relying, believing, accepting as true, having an opinion, having confidence or trust in someone or something.

Similar semantic contexts crop up in the case of religious faith which is subject to various interpretations. Some people one-sidedly emphasise the moment of placing trust in God, taking a risk, or making a commitment (Martin Luther, Rudolf Bultmann). Others question the cognitive value of faith (Friedrich D.E. Schleiermacher, Ludwig Feuerbach), regard it as awareness of life in the presence of God (Don Cupitt), or a form of interpreting the world by man in a state of absolute freedom (John Hick). The partisans of voluntarism believe that faith has no logical justification and its grounding is purely pragmatic (Immanuel Kant, Blaise Pascal, William James). The representatives of cognitive theories of faith underscore the relationship between man and God and acceptance of the revealed truths (John Locke, Jan Salamucha). Finally, some point to the multifaceted character of faith which: refers to God and the revealed truth; consists in a supernatural gift; has ecclesial context; is an act of intellect guided by wilful choice; is grounded in God's authority and credibility motives of the revelation (e.g. miracles, consistency of the teachings); presumes the activity

\footnotetext{
${ }^{1}$ P. Moskal, Czy istnieje Bóg? Zarys filozofii Boga, Pelplin 2002, p. 37.
} 
of the rational mind in the process of knowing God and the object of faith (Augustine of Hippo, Thomas Aquinas, Joseph Ratzinger, Walter Kasper) $)^{2}$.

Jewish religious thinker Martin Buber distinguishes two fundamental types of religious faith. One is based on placing trust in somebody, while the other - on accepting a state of matters as true. Both are similar in their lack of sufficient grounding, which stems not from any weakness of human reasoning but from the character of relationship with the trusted or accepted object. In both cases, rational arguments may not be the decisive factor. Trust consists in the contact between man and the trusted object. Acknowledgement consists in accepting everything man believes to be true. Naturally, trust may lead to acceptance of the truths and acceptance may inspire trust. The first type (the Jewish type of faith) is designated by Buber as enuma, while the other, more Greek in character - as pistis ${ }^{3}$.

Discussion on the nature of religious faith is related to the issue of revelation. In general understanding, revelation is an announcement, a declaration, a disclosure, a proclamation and an appearance ${ }^{4}$.

The understanding of revelation is different in every religious system, particularly regarding historical revelation, not the cosmic or eschatological revelation. God is its originator, man is the addressee, deification and salvation are the ends, while words and acts are the form. There is a range of revelation models offering the following types of understanding: 1) revelation as a doctrine, history, inner experience, dialectic presence and a form of awareness (Avery Dulles); 2) intellectual, personal, historical, anthropological, immanent, semeiological, and symbolic (Marian Rusecki); 3) propositional and those related to the history of salvation (John Hick, Richard Swinburne). The propositional, personalistic, dialogic, salvific,

2 Ibidem, p. 38-43; idem, Religia i prawda, Lublin 2008, p. 155-157.

3 M. Buber, Zwei Glaubensweisen, in: idem, Werke. Erster Band. Schriften zur Philosophie, München-Heidelberg 1962, p. 653, 654, 779, 781.

4 P. Moskal, Religia..., op.cit., p. 157. 
historical, semiotic, and symbolic aspects of salvation are frequently observed as well ${ }^{5}$.

According to Buber, the character of the revelation is essentially existential. It does not provide man with any specific cognitive content but allows him to experience the presence of another being. At this moment, three things occur. Firstly, man feels a connection with being. Secondly, the sense of man is confirmed. Thirdly, man is given the task of fulfilling the sense in the world with the use of his unique essence in its unique existence. Experiencing the presence of another being translates into an inner transformation of $\operatorname{man}^{6}$. By accentuating the existential dimension, Buber deprives the revelation of its noetic and propositional character ${ }^{7}$. The revelation is valuable in that it transforms man into a witness of another reality which becomes apparent thanks to the authenticity of a human being. However, the content of the sense remains an issue. Every sense presented for fulfilment in the world should have a content dimension. It seems impossible to consider a revelation that holds no content ${ }^{8}$.

The existential character of faith is also emphasised by Ireneusz Ziemiński, a Polish philosopher of religion who posits that faith rests on an existential commitment rather than a belief in the accuracy of any theses. The faithful believe that God exists, entrust Him with their fate, and express readiness to fulfil His will. Faith is not a philosophy but an experience. It comes to a climax in a mystical experience which allows man to directly feel God's presence ${ }^{9}$. A similar concept is put forward by Tomáš Halík. Referring to Old Testament tradition, the Czech thinker comprehends faith as Abraham's journey whose

5 Ibidem, p. 158-163.

${ }^{6}$ M. Buber, Ich und Du, in: idem, Werke. Erster Band. Schriften zur Philosophie, München-Heidelberg 1962, p. 152-153, 157; idem, On Judaism, New York 1967, p. 216.

7 M. Buber, Nachlese, Heidelberg 1966, p. 125-126; idem, Zwei Glaubensweisen, op.cit., p. 656.

8 A. Anzenbacher, Die Philosophie Martin Bubers, Wien 1965, p. 72, 107.

9 I. Ziemiński, Życie wieczne. Przyczynek do eschatologii filozoficznej, Poznań-Kraków 2013, p. 428-430. 
end and destination remain unknown to man. Thus, faith becomes a lifestyle. Conversely, religion (understood both as the consistency of reason with a set of truths and as a system of institutions and rituals) becomes a perversion of faith ${ }^{10}$. In the light of the above, ethicist Jan Kłos observes that no religion, and Christianity in particular, may be regarded as a set of truths learnt and adequately classified by reason for such an approach puts faith in shackles and leads to its collapse ${ }^{11}$. Other authors agree that, above all, religion (Christianity) is not a philosophical truth but an event. Faith may be compared to accepting a love confession that cannot be fully justified. The confession rests on the trust in the person speaking, the testimony, and the witnesses who keep mirroring that event in their lives and continuously maintain its trustworthiness ${ }^{12}$.

Thus, as affirmed by Józef Tischner, faith has a dialogical nature, as it freely involves the given answer of man to the call made by the revealing God ${ }^{13}$. Jarosław Gowin, one of Tischner's disciples, emphasises that authentic faith must be in the first place an expression of a personal choice and not only compliance with a social ritual. Man chooses his spiritual path on his own, guided by his own conscience and reason ${ }^{14}$.

According to Augustine of Hippo, faith is an issue of a different order, which may involve knowledge (the soundest type thereof) but, above all else, remains a matter of the heart ${ }^{15}$. Therefore, as observed

10 T. Halík, Europa: rany przeszłości i wyzwania jutra, transl. T. Dostatni, in: S. Zięba (ed.), Europa wspólnych wartości. Chrześcijańskie inspiracje w budowaniu zjednoczonej Europy, Lublin 2004, p. 131.

11 J. Kłos, John Henry Newman i filozofia. Rozum - przyświadczenie - wiara, Lublin 1999, p. 97.

${ }_{12}$ R. Buttiglione, J. Merecki, Europa jako pojęcie filozoficzne, transl. J. Tarnówka, Lublin 1996, p. 56-59.

13 J. Tischner, W krainie schorowanej wyobraźni, Kraków 1998, p. 70.

14 J. Gowin, Religia i ludzkie biedy. Ks. Tischnera spory z Kościołem, Kraków 2003 , p. 34.

15 Augustyn z Hippony, O Trójcy Świętej, transl. M. Stokowska, Poznań 1963, p. 350,352 . 
by Kłos, faith is primarily a living reality of the inner self, something to be experienced and not a set of ideas to contemplate and discuss. Therefore, faith should move a man from the inside. The experience of faith is a way of "following", "coming after". Above all, faith has a formative value; all knowledge is only a personal result of life experience ${ }^{16}$.

In this context, some thinkers make a distinction between faith and religion. It is their assumption that religious is institutional and faith - personal, since personal commitment is an important component of faith and a prerequisite for its survival ${ }^{17}$. Furthermore, religion refers to the external aspects of the relationship between man and God, whereas faith is concerned with the personal, spiritual experience. Religion is horizontal, whereas faith - vertical. Religion has its historical and cultural beauty, whereas faith is characterised by the presence of an encounter, a bond between the spirits of man and God, or the struggle untranslatable in full to the language of culture ${ }^{18}$.

Nevertheless, it seems unfounded to solely accentuate the existential character of faith, disregarding its cognitive dimension. In reality, faith is an action of holding certain beliefs with regard to imperceptible states of being. Faith consists also in accepting as true certain statements whose truthfulness is imperceptible. In this case, belief begins by choice. The statements are grounded in God as an epistemic authority, i.e. a truthful and competent being. Consequently, belief requires knowledge of God as a grounding for the acceptance of certain statements as true. The acceptance of statements must be preceded by knowledge of the existence and the nature of God (e.g. through natural cognition) and an understanding of their divine

16 J. Kłos, Pewność wobec niepewności. Szkic o filozofii wiary Johna H. Newmana, Lublin 2003, p. 97, 120-123.

17 M. Masłowski, Na marginesie wykładu Charles Taylora, Znak 10(2010), p. 48-49, 52-53.

${ }_{18}$ M. Pawliszyn, Logika wobec religii. Religia wobec logiki. Z badań nad filozofia religii o. Józefa Marii Bocheńskiego OP, Olsztyn 2006, p. 40. 
providence ${ }^{19}$. In contact with the surrounding world, man is able to gain elementary knowledge of God through reason ${ }^{20}$.

In the opinion of Zofia J. Zdybicka, a Polish philosopher of religion, the revelation takes the form of an enlightening contact with the religious object by the agency of various media (signs, symbols, and words). Man responds with faith, which refers to the reality beyond direct cognitive perception. Acknowledgement of any content is not forced by objective self-evidence but constitutes a wilful act preceded by the discernment of the value presented by the revealing religious object. Thus, faith involves cognition marked with personal commitment. The moment of voluntary acceptance is an important component of faith which differentiates it from a purely cognitive experience. Note that the initiative comes from the side of the revealing being. However, knowledge of religious truths alone does not constitute a religious act. What matters is their internal acceptance and acknowledgement as one's own. This assertion differs from the acquisition of purely informative knowledge for it is based on the power of trust ${ }^{21}$. According to Zdybicka, the assertion of a religious truth is affected by various media, both objective (e.g. signs) and subjective (e.g. personality type, attitude, cognitive sensitivity, etc.). Furthermore, cognition through faith is committed rather than purely theoretical. It is also difficult to convey and virtually impossible to verify in full ${ }^{22}$.

Józef Bocheński, a world-class logician, also emphasises that faith is an act of human reason which, hard-pressed by will, accepts a statement as true. The essence of faith lies in cognition, and its direct object - in a statement. The statement is accepted as true with no hesitations or reservations. The act of faith is always performed of one's own accord, i.e. it cannot be exacted by force or any evidence.

\footnotetext{
19 P. Moskal, Czy istnieje Bóg?..., op.cit., p. 44-48.

20 Z.J. Zdybicka, Bóg czy ,,sacrum”?, Lublin 2007, p. 95.

${ }^{21}$ Z.J. Zdybicka, Człowiek i religia. Zarys filozofii religii, Lublin 1993, p. 177-178, 187, 309.

22 Z.J. Zdybicka, Religia i religioznawstwo, Lublin 1988, p. 435.
} 
However, note that its occurrence is provoked not only by reason but also by emotions, imagination, and subconsciousness. Bocheński observes that faith may not be proven in any way. In his opinion, the only argument in favour of faith lies in the motives of credibility which provide rational grounds for accepting statements as true. There are two types of motives: theoretical and pragmatic. Theoretical motives, relating chiefly to witness credibility, are intended to provide an assurance that acknowledgement of the statement is a reasonable step. Pragmatic motives are supposed to prove that the statement or its consequences are consistent with the ideals espoused by $\operatorname{man}^{23}$.

Thus, faith is the attitude of man convinced of the truthfulness of certain assertions despite their empirical unverifiability. Faith may be also defined as a set of theses accepted in a religion. Faith is therefore a cognitive action, i.e. a method of acquiring information on a subject ${ }^{24}$.

In this framework, reason becomes a prerequisite for the Revelation and a vital component of the faith. God could not have revealed Himself if man was incapable of comprehending some truth about Him. Furthermore, reason is indispensable for understanding and interpreting the truths of the faith. Intellectual cognition is as necessary for the faithful as faith which grants them access to the life of the revealing God. Do not forget that faith rests on reason and perfects $i^{25}$, particularly as man has a rational nature which must find its fulfilment also in the sphere of faith ${ }^{26}$.

In conclusion, reason plays an important role in the process of the revelation and the development of faith. This is because acknowledging, knowing, and understanding certain truths which arise from the divine epistemic authority is an essential aspect of both revelation and faith. Since faith is a type of cognition, it has

23 J. Bocheński, Wiara, in: idem, Dzieła zebrane, Vol. 6, Religia, Kraków 1995, p. 205-209.

24 A.B. Stępień, Wstęp do filozofii, Lublin 1989, p. 105.

25 Z.J. Zdybicka, Bóg..., op.cit., p. 167-168.

26 Z.J. Zdybicka, Religia..., op.cit., p. 427. 
a propositional aspect as well. Thus, religious faith consists not only in experiencing a supernatural reality but also in accepting certain statements.

\section{THE CHARACTER OF MODERN RATIONALITY}

As emphasised by Mariusz Wojewoda, no single model of rationality has been established so far, but many possible concepts have been suggested. Therefore, one should not discuss rationality as such but only its different types. The comprehension of rationality is rooted in non-rational myths and metaphors related to culture, history, and tradition. The choice of tradition is determined by respect for the force of the arguments, the power to explain facts and events, or the influence of an authority figure. Thus, believing in any neutral criterion of rationality is misguided, and the search for such a criterion is doomed to fail. The establishment of a single model of rationality proves impossible, which should teach man intellectual humility and respect for different ways of interpreting the world. In addition, it is necessary to create complementary models of reasoning ${ }^{27}$.

Józef Życiński, a theologian and a philosopher of science, lists seven fundamental types of rationality, including: ontic rationality (non-chaotic character of physical processes; stability, mathematical accuracy, and vulnerability to idealisations observed in the natural world), cognitive rationality (internal consistency within a system of assertions), formal rationality (internal consistency within a formal system), content-wise rationality (higher level of grounding in the accumulated knowledge and a corresponding character of human cognition), common-sense rationality (consistency with common beliefs informed by traditions, habits, prejudices, or general agreement), methodological rationality (consistency with the methods of practising and developing science) and pragmatic rationality (a set of conditions of effective action). Thus, Życiński refuses to regard

${ }^{27}$ M. Wojewoda, Pluralizm aksjologiczny i jego implikacje we współczesnej filozofii religii, Katowice 2010, p. 112-116, 146-148. 
rationality as a monosemous notion. The establishment of a standard theory of rationality proves impossible also because theories evolve with the paradigm of practising science and their acceptance depends not only on objective criteria but also on subjective authorisation ${ }^{28}$. Ryszard Kleszcz, an epistemologist and a methodologist, discerns the following types of rationality: conceptual (precision, clarity, distinctness, and accuracy of language), logical (respecting the principle of non-contradiction and using the deductive method), epistemological (respecting the potential of the subject's cognitive apparatus in the process of cognition), methodological (respecting the scientific method), practical (adapting actions to the circumstances or the state of knowledge), axiological (actions consistent with the subject's hierarchy of values), and ontological (identity, noncontradiction, and having a reason for existence or the mathematicality and the "mathematicability" of existence $)^{29}$. John Hick, an analytic philosopher of religion, adds the category of empirical rationality. In his mind, religious beliefs are rational when based on a broadly understood religious experience and testimony ${ }^{30}$.

According to Tischner, plurality is a feature of not only rationalities but also rationalisms which, due to qualitative differences, cannot be converted into a common denominator. The Cracovian philosopher also points out that "rationality" is derived from the Latin word ratio, or a basis, a foundation, a principle of human thinking ${ }^{31}$. It could be said that the mental activity of man involves a wide array of methods, principles, motives, and premises. In this context, it should be emphasised that faith is also a rational reality since it has a basis and certain premises.

28 J. Życiński, Teizm i filozofia analityczna, Vol. 1, Kraków 1985, p. 187-207.

29 R. Kleszcz, O racjonalności. Studium epistemologiczno-logiczne, Łódź 1998, p. $44-85$.

30 J. Hick, Argumenty za istnieniem Boga, transl. M. Kuniński, Kraków 1994, p. $184-189$.

31 J. Tischner, Myślenie wedtug wartości, Kraków 2000, p. 430, 432, 434. 
Nowadays, the scientistic tendency to reduce rationality to its instrumental dimension prevails. The search for the essence of things has been abandoned and reason has been separated from transcendence and values. Among philosophers of science, it is a popular belief that science concerns itself with the rationality of means, which is the technical, instrumental rationality. In such a perspective, rationality becomes an instrument supposed to provide man only with effectiveness in action ${ }^{32}$.

Thus, the sphere of reason is limited to the empirically verifiable $\operatorname{cognition}^{33}$ and a conceptual calculation with the use of logic and mathematics ${ }^{34}$. The rational approach understood as instrumental rationality, in which appropriate calculation of means is sufficient to achieve natural goals, prevails. This approach is related to Weber's "disenchantment of the world"- the process of intellectualisation and rationalisation which deprives the world of any supernatural forces affecting human life. As a result, everything may be achieved by means of technology and calculation. Thus, the substantial reason which dominates in metaphysics and religion is losing ground ${ }^{35}$.

This tendency draws back to the philosophy of Descartes and Locke who laid the foundations for the concept of instrumental reason.

According to Descartes, the ability known as common sense or reason, which enables man to make sound judgments and to distinguish truth from falsehood, is inherently identical in all people. The philosopher had a propensity for mathematical sciences due to their certainty and self-evidence. Based on mathematics, he created a method wherein self-evidence became the basic criterion. According to the method, man should be guided only by reason and interpret things in a clear and distinct manner. The Cartesian programme aimed to achieve certainty through ideas and through

\footnotetext{
32 M. Bombik, Typy racjonalności. Cz. 1, SPCh 37(2001), p. 28, 36.

33 J. Ratzinger, Europa. Jej podwaliny dzisiaj i jutro, transl. S. Czerwik, Kielce 2005, p. 92-93.

34 A. Bronk, Rozumienie, dzieje, język, Lublin 1982, p. 131.

35 A. Szahaj, Co to jest postmodernizm?, „Ethos” 33-34(1996), p. 65-66.
} 
clear and distinct reasoning. Thus, all that is not clear and distinct cannot be declared true. All that is only probable must be declared false ${ }^{36}$.

As pointed out by the Canadian philosopher Charles Taylor, Descartes attached special importance to reason as the entity which constructs reality from self-evident ideas. Thus, he reduced human rationality to the ability to construct an ordered reality. As a result, in the Cartesian framework, both the inner world of the psyche and the outside world of material things are subordinate to the instrumental governance of reason. Reason is of a procedural nature as it creates norms helpful in ordering one's life and the world. Therefore, order is no longer discovered in the world but is rather constructed by $\operatorname{man}^{37}$. Yet, instrumental reason is unable to grasp beings and goals present in the universe $\mathrm{e}^{38}$.

As observed by J. Kłos, if man is reduced to the function of clear and distinct reasoning, there is no place for the certainty of faith. Meanwhile, in the biblical tradition, man is summoned to act upon a leap of faith and not solely reason, as exemplified by the case of Abraham. Kłos takes issue with the entire concept of the clarity of knowledge in the context of faith. God does not lead man along the path of clear knowledge where everything is rationally explained. In the relationship with God, speculative reason plays a limited role, although it may be enlightened by God. However, faith is more of a meandering path marked with a lack of clear understanding. There is a fine line between knowledge and trust. Sometimes, man makes a misstep. Furthermore, it seems that a faithful man desires mostly to come into a personal relationship with God and not to unravel His mysteries. Above all, faith is a relationship in which man feels

36 R. Descartes, Rozprawa o metodzie, transl. W. Wojciechowska, Warszawa 1981, p. 3-4, 9-11, 20-25, 32-49.

37 Ch. Taylor, Philosophical Arguments, Cambridge (Ma)-London 1995, p. 4-6; idem, A Secular Age, Cambridge (Ma)-London 2007, p. 164-171; idem, Sources of the Self. The Making of the Modern Identity, Cambridge (Ma) 2001, p. 143-152, $155-156$.

38 S. Macedo, Cnoty liberalne, transl. G. Łuczkiewicz, Kraków 1995, p. 256. 
the closeness of God and trusts Him, although the human mind often remains in the dark. Thus, faith is accepted not due to its convincing arguments on an intellectual level but chiefly because of the Person being its object. Man believes God and in $\operatorname{God}^{39}$.

The English empiricist J. Locke also contributed to the establishment of the concept of instrumental reason. According to Locke, if a person accepts an assertion based on weak evidence or low probability, he or she becomes a slave and is at fault. Locke favoured knowledge, which is based on intuition, direct ideas and reasoning. Knowledge becomes certain upon proving the consistency or inconsistency of two ideas which remain in a stable relationship. Meanwhile, faith is only a matter of probability and has no reference to its object. Probability is based on the consistency of an object with our knowledge, experience and the testimony of others. It stems from the observation of facts or a speculation. Thus, there are various degrees of acknowledging the truth, ranging from absolute certainty to doubt ${ }^{40}$.

Taylor observes that the legacy of Locke's philosophy includes the concept of the "punctual self" and the atomistic theory of mind. According to this theory, the mind is composed of ideas (atoms) created as the senses are stimulated by invisible atoms. The ideas come together in a mechanistic process of association. The punctual mind is disengaged, not only from the body and all external beings but also from all external authority figures and senses. A human being exists as a self-conscious authority which orders and corrects all dimensions of reality. The self autonomously gives life an orientation by choosing goodness. The choice is made with reference to the feelings of pleasure and pain ${ }^{41}$.

Taylor believes that the concepts of Descartes and Locke have helped people perceive the mind as an external observer which distances itself from the world and controls it with the use of reason.

39 J. Kłos, John Henry Newman..., op.cit., p. 89-90, 104, 106, 188.

40 J. Locke, Badania dotyczace rozumu ludzkiego, transl. B. Gawecki, Vol. II, Warszawa 1955, p. 387-392, 400-401, 476.

${ }^{41}$ Ch. Taylor, Sources..., op.cit., p. 49-50, 165-173. 
As a result of the new hegemony of reason, the instrumental attitude is adopted with regard to not only external objects but also psychical contents. Reason has lost its substantiality and has acquired a procedural character ${ }^{42}$.

Experiences related to technological production, marked with functionality, effectiveness, and increased standard of living, have also defined the concept of the instrumental reason and the related rationality. However, the new take on rationality may prove destructive in the longer run as it takes into account only the potential of technology ${ }^{43}$.

It seems that limiting rationality to its instrumental and scientific dimension, highlighted only within a certain tradition, is unacceptable. Note that there are many traditions and concepts of rationality. Man should accept their plurality and, thus, change his way of understanding and discussing the world ${ }^{44}$. At times, limiting rationality to the instrumental and scientific dimension is called the "myth" of the Enlightenment which needs to be rejected ${ }^{45}$.

\section{RELIGIOUS FAITH AND MAN AS A RATIONAL BEING}

The domination of instrumental reason is related to the marginalisation of the substantial rationality. Goal-oriented rationality is given priority to the detriment of rationality oriented at values and transcendence ${ }^{46}$. As a result, man is denied the opportunity to know objective truth and goodness. Practical reason is reduced

42 Ibidem, p. 143-158, 234-237.

43 J. Ratzinger, op.cit., p. 39-41.

${ }^{44}$ M. Wojewoda, Pluralizm, wartości i prawda we współczesnych dyskusjach filozoficznych, in: D. Kubok (ed.), Prawda i świat człowieka. Studia i szkice filozoficzne, Katowice 2008, p. 147.

${ }^{45}$ Ch. Taylor, Dilemmas and Connections. Selected Essays, Cambridge (Ma)London 2011, p. 322-332.

46 V. Possenti, Religia i życie publiczne. Chrześcijaństwo w dobie ponowożytnej, transl. T. Żeleźnik, Warszawa 2005, p. 35.234-235. 
to its instrumental and technical functions, whereas the importance of scientific reason is accentuated. Scientific reason can objectify and drive technological progress. It plays a role in certain spheres of life, but its domination may lead to relativism and pragmatism ${ }^{47}$.

Therefore, it seems that man should return to the AristotelianThomistic tradition whose representatives ruminated over the mental faculties of man. To describe them, the thinkers used three important terms: mind, intellect and reason. Mind was understood as the entire spiritual sphere of human faculties, particularly the cognitive faculty or some its functions. Thus, the difference between the intellect, or the mental cognitive faculty, and its functional names, is not based in reality but only in thought. Strictly speaking, the term "intellect" referred to the cognitive faculties which allowed man to grasp his existence and know the nature of things in a simple, direct manner. The same human faculty when applied to acquiring knowledge on reality by way of reasoning, drawing conclusions from premises, was called reason. Generally, human cognition was based on reasoning ${ }^{48}$.

The legacy of this thought is the distinction between ratio and intellectus, i.e. reason in contact with all things empirical and apparent in action versus intellect which pervades the deepest layers of existence ${ }^{49}$. The intellect seems to play a special role in faith as it opens man to the mysteries of existence.

That is why Halík appeals to return to the medieval intellectus, which is the spiritual faculty of man, giving him an insight into the mystery ousted by analytic reason - ratio $^{50}$. According to the Czech thinker, intellectus is a type of light which mirrors the light of God. In

47 H. Juros, Kościót. Kultura. Europa, Lublin-Warszawa 1997, p. 94-97.

48 M.A. Krąpiec, Ja-człowiek. Zarys antropologii filozoficznej, Lublin 1974, p. 171-172; P.S. Mazur, Intelekt, in: A. Maryniarczyk (ed.), Powszechna Encyklopedia Filozofii, Vol. 4, Lublin 2003, p. 867, 870; S. Swieżawski, Święty Tomasz na nowo odczytany, Poznań 1995, p. 182.

49 J. Ratzinger, op.cit., p. 92-93.

50 T. Halík, Wzywany czy niewzywany, Bóg się tutaj zjawi. Europejskie wykłady z filozofii i socjologii dziejów chrześcijaństwa, transl. A. Babuchowski, Kraków 2006, p. 233. 
turn, ratio is a tool for achieving success and changing the world. Yet Halik highlights that only the intellect expands the cognitive horizons of man and allows him to unravel the mystery of existence ${ }^{51}$. Leszek Kołakowski also points to the insufficiency of analytic reasoning in religion. In his opinion, the certainty of faith is the outcome of moral commitment rather than the certainty known in mathematics ${ }^{52}$.

Furthermore, according to Benedict XVI, analytic reason is marked with pride. Although it is deemed self-sufficient, it remains closed to contemplation and the search for an overarching divine Truth $^{53}$. Such a truth may be discovered by intuition rather than discourse and analysis ${ }^{54}$.

In addition, Andrzej Szahaj evokes the important distinction made by Max Horkheimer, a German philosopher and sociologist, who distinguished "subjective" and "objective" reason. The former term refers to the instrumental reason whose activity fits the model of ends and means. The means are evaluated in terms of their usefulness for achieving specific goals. Reason gets involved in the process of subduing nature and the achievement of particular goals dependent on individual taste and inclinations. However, in the process of instrumentalisation, thought is reduced to the level of usefulness and results in objectification. Conversely, "objective reason", whose concept was presented especially by Plato, allows man to uncover the fundamental structure and nature of the world. Objective reason

${ }^{51}$ T. Halík T., Noc spowiednika. Paradoksy małej wiary w epoce postoptymistycznej, transl. A. Babuchowski, Katowice 2007, p. 152.

${ }^{52}$ L. Kołakowski, Religia. Jeśli Bóg nie istnieje. O Bogu, diable, grzechu i innych zmartwieniach tak zwanej filozofii religii, Kraków 1987, p. 29, 32.

${ }_{53}$ Benedykt XVI, Sekularyzacja jest trudna próba dla Kościoła, OsRomPol 4(2008), p. 36.

54 M. Wojewoda, Pluralizm aksjologiczny..., op.cit., p. 118-119. Some believe that religion and religious truth seem to have their own logic which refers to intuition, belief, and emotions rather than "solid" rationality, cf. M. Hułas, Źródła sekularności. Analiza wybranych aspektów sekularyzacji, „Studia Nauk Teologicznych PAN" 9(2014), p. 38. 
is focused on the truth about the world and the highest good ${ }^{55}$. It not only deciphers the structure of the world but also participates in its substantial order. Thus, it has a similar character ${ }^{56}$. Substantial reason can discover that which is true and good for $\operatorname{man}^{57}$. Therefore, it should be more appreciated and exploited in the process of faithrelated cognition.

It seems that an appreciation of substantial reason allows to restore the correlation between faith and reason. Even more so as they both need to purify each other. To this end, it is necessary to accentuate not only the ability of reason to construct and calculate but also its openness to the basic values of truth and goodness ${ }^{58}$.

Restoring the correlation between faith and reason is of particular importance in the sphere of religion, which is an element of the internal world of a person. Man goes deep inside himself, opens up to the internal voice of his existence, and equates it with the voice of $\operatorname{God}^{59}$. Possibly the most important journey in the life of any man is the journey into himself. It is not a step into an abyss but towards God. That inner contact with God is secret, cannot be measured, and defies scientific observation ${ }^{60}$. It provides man with faith-specific knowledge, showing the truth which comes from and is guaranteed by God ${ }^{61}$.

According to Kłos, faith often has to confront radical rationalism which puts a spotlight on the instrumental reason, prevailing also in science. Representatives of this rationalism attempt to fit the truths of the faith into a coherent system and justify them with strong arguments. However, Kłos believes that this rationalism is appropriate only in the case of natural sciences. In the context of religion, it often

55 A. Szahaj, Teoria krytyczna szkoły frankfurckiej, Warszawa 2008, p. 44-45.

56 E. Morawiec, Wybrane filozoficzne koncepcje rozumu ludzkiego i racjonalność, Warszawa 2014, p. 29.

57 S. Macedo, op. cit., p. 256

58 J. Ratzinger, op.cit., p. 58-62, 78-79, 93-95.

59 J. Kłos, John Henry Newman..., op.cit., p. 213.

${ }^{60}$ J. Kłos, Pewność..., op.cit., p. 34-35.

${ }_{61}$ Z.J. Zdybicka, Bóg..., op.cit., p. 165. 
proves pointless due to the lack of a proper goal. The fundamental aim of religion is not to coin terms, draw conclusions, or formulate definitions, but rather to live in the truth. The truth is revealed in an influence exerted by some people on others. This influence leads to not only intellectual pleasure but also a transformation, shaping the character of a person. Conversely, rationalism based on logical speculation does not cause internal transformation. In the context of theology and teaching the principles of the faith, rationalism converts living faith into a sphere of pointless considerations and deliberations. As a result, faith ceases to be a life programme allowing man to go towards God and change his existence ${ }^{62}$. Furthermore, if faith is a relationship with God and a certain reality placed in the hands of man by Him, man should believe because of God Himself and not the internal consistency of the faith. Faith is more than the arguments. Oftentimes, it is born even in spite of the arguments ${ }^{63}$. Although faith is an act of reason, it does not necessarily rest on research, arguments, or evidence ${ }^{64}$. As emphasised by Anselm of Canterbury, if the investigated matter is unfathomable, presenting a proof at all cost is inessential ${ }^{65}$.

According to Kłos, making judgments and affirming the truth remains an integral component of faith. However, instead of being based on sound evidence, faith often rests on probability, presumption, and instinctive feeling. Reflection may allow man to reach a certain level of personal certainty. Man cannot have adequate logical apparatus to prove it, which does not undermine the certainty itself. However, proving the certain is often impossible. In the context of the faith, cognition is related to the entire human personality and cannot be treated as a purely logical process. According to Kłos, it cannot be separated from emotions or the imagination. Therefore, truths

${ }^{62}$ J. Kłos, John Henry Newman..., op.cit., p. 74, 95-96, 195.

63 J. Kłos, Pewność..., op.cit., p. 68-69.

${ }^{64}$ J. Kłos, John Henry Newman..., op.cit., p. 215.

${ }^{65}$ Anzelm z Canterbury, Monologion. Proslogion, transl. T. Włodarczyk, Warszawa 1992, p. 115. 
of the faith are not chosen with the use of man's logical apparatus; they are an expression of man as a whole. The certainty of faith is not solely a form of internal conviction of a person but also a type of an existential experience. Faith should pervade the entire essence of man, even if he cannot always support his beliefs with arguments which do actually exist ${ }^{66}$.

Reason, as an important element of the human being, plays a crucial role in faith as a type of existential existence but it cannot be limited to the instrumental dimension. Human rationality is not oriented solely at the effectiveness and usefulness of action. It also evinces an ability to grasp structures, beings, and values present in the world. Man needs a form of rationality which takes this into account ${ }^{67}$. Therefore, Taylor believes using instrumental reason to be insufficient and dangerous, particularly for religious faith. It desensitises man to the so-called "enchanted world", or the world of spiritual beings, and thus severs man's link with the source of life, depth, and sense of his existence ${ }^{68}$.

This is because man should search for other types of rationality as a tool of knowing the truth. Afterwards, the truth should become the principle of thought and action, i.e. it should lead to a testimony ${ }^{69}$. In faith, intellectual cognition and substantial reason should be appreciated as they allow man to pervade the deepest layers of existence and grasp truth, goodness and the sense of reality.

\section{CONCLUSIONS}

Those analyses were aimed to determine the nature of religious faith and various types of rationality, with special emphasis on instrumental rationality. Furthermore, they sought to characterise the link between faith and reason, as well as the insufficiency

\footnotetext{
66 J. Kłos, John Henry Newman..., op.cit., p. 93-94, 190-191, 227.

${ }^{67}$ J. Kłos, Pewność..., op.cit., p. 57.

${ }^{68}$ Ch. Taylor, Dilemmas..., op.cit., p. 354-357.

69 H. Juros, op.cit., p. 99-100.
} 
of instrumental reason in the sphere of faith. Instrumental reason is limited to the practical pursuits, which forces man to rely on a different type of mental activity in other spheres of life, including religiousness.

It should be emphasised that there are many concepts of religious faith related to various types of the revelation. Two main concepts of the revelation may be discerned: existential and propositional. The former focuses on the moment of experiencing the presence of the absolute, whereas the latter accentuates the content dimension of the revelation presented as a set of theses. Therefore, faith may be based either on experience and mysticism or on cognition. It seems necessary to find a "golden mean" between those two concepts. Faith is an experience, a commitment, and a lifestyle, but also a set of ideas and statements accepted by man by the power of trust. Reason gains importance at the moment of revealing religious truths and in the process of their understanding and interpretation. Therefore, it is vital to search for correlations between human reason and faith.

Simultaneously, note that man has a single mental cognitive faculty which serves a range of functions. It may grasp the nature of beings in a simple and direct manner (intellect) or acquire knowledge on the world by means of discourse (reason). In the early modern period, the instrumental rationality of man came into spotlight. In this concept, the activity of reason was limited to calculation oriented at effectiveness and functionality, as well as arbitrary construction of a world order. It remains closed to contemplation and deciphering the structure of reality. It has also lost the insight into the mystery and the sense of reality, which may lead to the loss of faith. However, the cognitive activity of man cannot be reduced solely to the work of the instrumental reason. To the contrary, man should aim to provide an integral concept of his rationality. Reduction of rationality to a single type leads to the impoverishment and crippling of the entire man, stripped of the dimensions of existence characteristic of the personal being. Man is oriented not only to the effectiveness and efficiency of his actions but also at the world of mystery, sense, and value of existence. 
Note that man has the ability to penetrate and easily grasp the deepest layers of existence with his intellect and to decipher the structure of existence and discover values with the use of his substantial reason. Those faculties of the mind open the door to transcendence, revealed truths and faith.

In conclusion, two other important matters should be discussed. Firstly, rationality of religion does not imply that religion is rationalist, i.e. reduced strictly to the dimension of reason. Religion does not only dispute reason and does not oppose the natural rational cognition. Secondly, rationality of faith is fundamentally different from rationality of science. Scientific rationality is essentially theoretical. Faith-based rationality is practical because it aims not to satisfy the human thirst for knowledge but to open the door to a certain lifestyle.

\begin{abstract}
The purpose of this article is to determine the nature of religious faith and various types of rationality, with special emphasis on instrumental rationality, to characterise the link between faith and reason, and to reveal the insufficiency of instrumental reason in the sphere of faith. Instrumental reason is limited to the practical pursuits, which forces man to rely on a different type of mental activity in other spheres of life, such as religiousness. The paper is divided into three parts. The first section presents the nature of religious faith (religious faith as a psychological attitude of the followers and as a set of theses accepted in a given religion; existential and cognitive dimension of faith; the relationship between faith and revelation; assertion of religious truth). The second section outlines the nature of modern rationality (pluralism of rationality, its types, instrumental reason). The third section focuses on the relationship between religious faith and human reason (ratio, substantial reason, intellect).
\end{abstract}

Keywords: religious faith, instrumental reason, pluralism of rationality, substantial reason, intellect 


\section{Wiara religijna a typy racjonalności Streszczenie}

Celem artykułu jest określenie natury wiary religijnej i różnych rodzajów racjonalności, ze szczególnym uwzględnieniem racjonalności instrumentalnej, a także ukazanie charakteru powiązania wiary i rozumu oraz niewystarczalności rozumu instrumentalnego w obszarze wiary. Jego aktywność ogranicza się bowiem jedynie do fragmentu praktycznej działalności człowieka, który w innych sferach swego życia, w tym religijności, domaga się używania innego rodzaju racjonalności. Artykuł składa się z trzech części, w których przedstawiono następujące zagadnienia: 1. charakter wiary religijnej (wiara religijna jako postawa psychologiczna wyznawców i jako zespół tez zaakceptowanych w danej religii; egzystencjalny i kognitywny wymiar wiary; związek między wiarą a objawieniem; asercja prawdy religijnej); 2. natura współczesnej racjonalności (pluralizm racjonalności, jej typy, rozum instrumentalny); 3. związek między wiarą religijną a rozumnością człowieka (ratio, rozum substancjalny, intelekt).

Słowa kluczowe: wiara religijna, rozum instrumentalny, pluralizm racjonalności, rozum substancjalny, intelekt

\section{References}

Anzelm z Canterbury, Monologion. Proslogion, transl. T. Włodarczyk, Warszawa 1992.

Anzenbacher A., Die Philosophie Martin Bubers, Wien 1965.

Augustyn z Hippony, O Trójcy Świętej, transl. M. Stokowska, Poznań 1963.

Benedykt XVI, Sekularyzacja jest trudna próbą dla Kościoła, OsRomPol 4(2008),

p. $35-36$.

Bocheński J., Wiara, in: idem, Dzieła zebrane, Vol. 6, Religia, Kraków 1995, p. 205-225.

Bombik M., Typy racjonalności. Cz. 1, SPCh 37(2001), p. 5-42.

Bronk A., Rozumienie, dzieje, język, Lublin 1982.

Buber M., Ich und Du, in: idem, Werke. Erster Band. Schriften zur Philosophie,

München-Heidelberg 1962, p. 77-170.

Buber M., Nachlese, Heidelberg 1966.

Buber M., On Judaism, New York 1967.

Buber M., Zwei Glaubensweisen, in: idem, Werke. Erster Band. Schriften zur

Philosophie, München-Heidelberg 1962, p. 651-782. 
Buttiglione R., Merecki J., Europa jako pojęcie filozoficzne, transl. J. Tarnówka, Lublin 1996.

Descartes R., Rozprawa o metodzie, transl. W. Wojciechowska, Warszawa 1981.

Gowin J., Religia i ludzkie biedy. Ks. Tischnera spory z Kościołem, Kraków 2003.

Halík T., Europa: rany przeszłości i wyzwania jutra, transl. T. Dostatni, in: S. Zięba (ed.), Europa wspólnych wartości. Chrześcijańskie inspiracje $w$ budowaniu zjednoczonej Europy, Lublin 2004, p. 127-145.

Halík T., Noc spowiednika. Paradoksy matej wiary w epoce postoptymistycznej, transl. A. Babuchowski, Katowice 2007.

Halík T., Wzywany czy niewzywany, Bóg się tutaj zjawi. Europejskie wykłady z filozofii i socjologii dziejów chrześcijaństwa, transl. A. Babuchowski, Kraków 2006.

Hick J., Argumenty za istnieniem Boga, transl. M. Kuniński, Kraków 1994.

Hułas M., Źródła sekularności. Analiza wybranych aspektów sekularyzacji, „Studia Nauk Teologicznych PAN" 9(2014), p. 37-53.

Juros H., Kościół. Kultura. Europa, Lublin-Warszawa 1997.

Kleszcz R., O racjonalności. Studium epistemologiczno-logiczne, Łódź 1998.

Kłos J., John Henry Newman i filozofia. Rozum - przyświadczenie-wiara, Lublin 1999.

Kłos J., Pewność wobec niepewności. Szkic o filozofii wiary Johna H. Newmana, Lublin 2003.

Kołakowski L., Religia. Jeśli Bóg nie istnieje. O Bogu, diable, grzechu i innych zmartwieniach tak zwanej filozofii religii, Kraków 1987.

Krąpiec M.A., Ja-człowiek. Zarys antropologii filozoficznej, Lublin 1974.

Locke J., Badania dotyczace rozumu ludzkiego, transl. B. Gawecki, Vol. II, Warszawa 1955.

Macedo S., Cnoty liberalne, transl. G. Łuczkiewicz, Kraków 1995.

Masłowski M., Na marginesie wykładu Charles Taylora, Znak 10(2010), p. 48-54.

Mazur P.S., Intelekt, in: A. Maryniarczyk (ed.), Powszechna Encyklopedia Filozofii, Vol. 4, Lublin 2003, p. 862-871.

Morawiec E., Wybrane filozoficzne koncepcje rozumu ludzkiego i racjonalność, Warszawa 2014.

Moskal P., Czy istnieje Bóg? Zarys filozofii Boga, Pelplin 2002.

Moskal P., Religia i prawda, Lublin 2008.

Pawliszyn M., Logika wobec religii. Religia wobec logiki. Z badań nad filozofia religii o. Józefa Marii Bocheńskiego OP, Olsztyn 2006.

Possenti V., Religia i życie publiczne. Chrześcijaństwo $w$ dobie ponowożytnej, transl. T. Żeleźnik, Warszawa 2005.

Ratzinger J., Europa. Jej podwaliny dzisiaj i jutro, transl. S. Czerwik, Kielce 2005. 
Stępień A.B., Wstęp do filozofii, Lublin 1989.

Swieżawski S., Święty Tomasz na nowo odczytany, Poznań 1995.

Szahaj A., Co to jest postmodernizm?, „Ethos” 33-34(1996), p. 63-78.

Szahaj A., Teoria krytyczna szkoty frankfurckiej, Warszawa 2008.

Taylor Ch., Dilemmas and Connections. Selected Essays, Cambridge (Ma)-London 2011.

Taylor Ch., Philosophical Arguments, Cambridge (Ma)-London 1995.

Taylor Ch., A Secular Age, Cambridge (Ma)-London 2007.

Taylor Ch., Sources of the Self. The Making of the Modern Identity, Cambridge (Ma) 2001.

Tischner J., Myślenie wedtug wartości, Kraków 2000.

Tischner J., W krainie schorowanej wyobraźni, Kraków 1998.

Wojewoda M., Pluralizm, wartości i prawda we współczesnych dyskusjach filozoficznych, in: D. Kubok (ed.), Prawda i świat człowieka. Studia i szkice filozoficzne, Katowice 2008, p. 135-154.

Wojewoda M., Pluralizm aksjologiczny i jego implikacje we współczesnej filozofii religii, Katowice 2010.

Zdybicka Z.J., Bóg czy ,sacrum”?, Lublin 2007.

Zdybicka Z.J., Człowiek i religia. Zarys filozofii religii, Lublin 1993.

Zdybicka Z.J., Religia i religioznawstwo, Lublin 1988.

Ziemiński I., Życie wieczne. Przyczynek do eschatologii filozoficznej, Poznań-Kraków 2013.

Życiński J., Teizm i filozofia analityczna, Vol. 1, Kraków 1985.

Karol Jasiński - prezbiter archidiecezji warmińskiej; doktor habilitowany nauk humanistycznych w zakresie filozofii; pracownik naukowo-dydaktyczny Wydziału Teologii Uniwersytetu Warmińsko-Mazurskiego w Olsztynie. 